\title{
Conceptual Framework for Developing an ERP Module for Quality Management and Academic Accreditation at Higher Education Institutions: The Case of Saudi Arabia
}

\author{
Mohammad Samir Abdel-Haq \\ College of Business / Management Information System Department \\ Dar Al Uloom University, Riyadh, Kingdom of Saudi Arabia
}

\begin{abstract}
As a result of the high priority given by universities in Saudi Arabia to the implementation of quality systems and achieve international and local academic accreditation, especially NCAAA, as well as, academic accreditation standards require the provision of a set of data, documents, reports and evidence distributed among the various departments of the university (academic and non-academic), which must be provided periodically and annually. These universities need to provide an integrated system between these departments to cover the requirements of quality and academic accreditation. On the other hand, there are ERP systems that suit the organizational environment of the university, but these systems did not implement a module to cover quality assurance requirements or academic accreditation. This study proposed a framework includes ERP module for quality requirements and academic accreditation to facilitate the collection of required data from various sources within the university and helps to provide the necessary reports and statistics, where the module organizes the necessary processes for quality and accreditation by providing a special database and through linking with the other subsystems at the university.
\end{abstract}

Keywords-Quality assurance; academic accreditation framework; ERP module

\section{INTRODUCTION}

Enterprise resource planning (ERP) systems are widely used by public and private organization. ERP consists of integrated application software modules aims to integrate all business processes and functions in a central database to improve productivity, quality and competitiveness for the organization, in addition to the ability of the ERP system to deal with a rapidly changing environment and overcome the limitations of legacy systems [1]. Recently, universities around the world have begun to move to ERP instead of having multiple management and organizational information systems at the university that may not be well interconnected, hindering inter-departmental processes [2]. On the other hand, current information systems may not provide strategic or historical analysis about students, courses and staff [3]. ERP system for universities is defined as "an information technology solution that integrates and automates recruitment, admissions, financial aid, student records, and most academic and administrative services" [4].
There are many reasons encourage the universities to adopt ERP system, such as global trends and government directives for universities to create an effective learning environment and to improve their performance and efficiency [5] especially in the Kingdom of Saudi Arabia, one of the most important trend which increase the demand of adoption ERP system is to meet the quality requirements and the academic accreditation standards (institutional or academic program level) of the Education Evaluation Commission - National Center for Academic Accreditation and Assessment (NCAAA), which aims to meet the expectations of stakeholders such as students, government and the labor market by developing competitive educational environments in those universities and ensuring continuous improvement in them. Quality assurance processes in HEI in KSA should cover all sectors of the institution to assure the effective integration with the administrative, planning processes and produce database and evidence-based performance indicator relating to NCAAA standards [6].

The accreditation is not easy process from the perspective of most faculty members as they have the misconception that it is an exhausting time consuming, not to say complex and unnecessary process [7], and there are some challenges, such as how to collect, aggregate, analyze data and collect evidences, then developing corrective action and future plans as needed based on NCAAA accreditation standards such as Strategic Planning indicators, Governance Systems, Teaching and Learning process, Student Records \& achievements, Faculty \& Staff Records, Institutional Resources management (Financial Resources, Information Technology, Facilities and Equipment and Safety and Risk Management), in addition to Research and Innovation and Community Partnership [7].

Little research has been conducted on ERP implementations in universities compared to other environments [1] [5]. Previous research has addressed the characteristics and components of ERP systems that are appropriate to the environment of educational organizations, especially universities, such as the use of ERP systems in the process of learning, teaching and classroom organization [8].

ERP systems vendors for HEIs such as Oracle, SAP, People Soft and Jenzabar did not implement a module to cover quality assurance requirements or academic accreditation [9], so these systems need to contain a special module to meet the 
requirements of quality and academic accreditation, including plans, reports, performance indicators and a survey of academic and non-academic services at the university, the difficulty in collecting such data hinders quality processes and delays academic accreditation and negatively affects the performance of the quality team and faculty to meet those requirements [6] [7]. The existence of a ERP module for quality requirements and academic accreditation greatly facilitates the collection of this data from various sources within the university and helps to provide the necessary reports and statistics for workers on this type of projects, where the module organizes the necessary processes for quality and accreditation by providing a special database and through linking with the other subsystems at the university.

However, quality and accreditation requirements call for research topics that attempt to add improvement to ERP systems to consider the collection, processing, storage and retrieval of data related to evidence, performance indicators, user surveys on services, learning resources, student results, statistics related to scientific research and community service, as well as follow-up implementation. Administrative and academic processes in line with the requirements of quality and academic accreditation, especially as these data are distributed across several departments in the university, and need an integrated system such as ERP system works to link these processes with each other through the development of a new module to fulfill the requirements of quality and academic accreditation processes that help decision makers at the university to study the strengths, weaknesses, opportunities and threats to build improvements plans and follow-up implementation.

This study proposes a conceptual framework to merge a new module to handle quality requirements and accreditation process as an attempt to enrich research topics in ERP in the higher education sector especially in Saudi Arabia. This study will review the modules of the ERP system that are suitable for the university environment to determine the common ERP Modules between ERP providers that are required for academic and administrative processes. This study also proposes a module for quality and academic accreditation Called QAAM (Quality Assurance and Accreditation Module) and linking this module with common ERP modules to help the university meet the standards imposed by the accreditation bodies.

\section{RESEARCH BACKGROUND}

\section{A. ERP Systems in Higher Education Institutions}

ERP "is an information system software that aims to integrate all business processes and functions in a central database. This boosts the management of business resources (finance, production, human resource, materials, etc.)" [10]. Higher education institutions as one of important sectors around the worlds have been influenced by global trends to adopt new technologies aim to improve the performance and efficiency [1]. Universities have relied heavily on information systems for several years, while increased attention has been given to ERP systems to cover organizational activities and processes and ensure their integration, with the aim of achieving significant cost savings as well as improving performance and results and an opportunity to update procedures and align them with perceived 'best practices' [2]. Integrated information system such as ERP helps the university to provide high quality services to the stakeholders measured in terms of ease of access, complete coverage of all needs and availability of information, allow university context to be more flexible to match the continuous evolutions in higher education sector. On the other hand, University ERP system provides the instruments to support the governance processes, providing the data and analysis necessary for strategic planning and control which enable the strong development area for the university to represent high delivery of services for students, teachers, researchers and community demands [3]. University ERP systems can provide academic and non-academic entities including colleges and departments with completely functional applications [1] [11] which enable users to access students' information, academic records, and other data needed to complete their daily work [12], this accessibility and availability will improve business processes and services provided to the faculty, students, and employees [13].

In Kingdom of Saudi Arabia there are (43) universities, (29) government universities and (14) private universities are sited on the ministry of education website (www.moe.gov.sa) three of them have an experience in ERP systems (1) King Abdul Aziz University, ERP System is ODES plus. (2) King Saud University, ERP System is MADAR. (3) King Fahd University, ERP System is Moraslat. These three systems cover the following administrative sectors: (1) Human resource. (2) Financial management. (3) Procurement management. (4) Where house (store) management. (5) Student registration management. (6) Library management [14]. The most known ERP vendors in Saudi Arabia Saudi Arabia are SAP, Oracle, PeopleSoft and JD Edward [14].

Table I shows the most important requirements of what (functional requirements) higher education ERP system should do, or how will do (non-functional requirements: performance characteristic of the system).

\section{B. Quality and Academic Accreditation in HEIs in Saudi Arabia}

In recent decades, governments in various countries have called on institutions of higher education to pay more attention to the quality of education and to improve learning outcomes, to develop the country's social and economic competencies and promote them among nations [15]. The International Network for Quality Assurance Agencies in Higher Education (INQAAHE) considered the quality assurance in HEIs as a process of establishing stakeholder confidence that provision fulfils expectations or measures up to threshold minimum requirements (Good Practice), which embraces input, process and outcomes [16]. In general, quality in higher education is a continuous development process based on quality policies, procedures to achieve the institution mission, values and stakeholder needs and expectations [17]. Quality assurance and Accreditation in HEIs is considered as one of the major processes in the development of higher education which is connected to the components of the educational process such as (students, teaching staff, programs, teaching methods, facilities and equipment, etc.) [18]. Accreditation is defined as "a process whereby officially appointed external regulatory 
bodies, accountable at government level, evaluate educational institutions sing established criteria, standards and procedures" [19]. The National Center for Academic accreditation and Assessment (NCAAA) in Saudi Arabia is established to improve the quality of higher education and to help universities to achieve international quality standards in the education sector in the provision of high-quality teaching, learning, research and community service [20]. All universities and academic programs in Saudi Arabia should achieve NCAAA academic accreditation [19] through well-defined processes based on quality standards and set of KPIs. Higher education institutions in Saudi Arabia are required to establish internal quality assurance systems that ensure high levels of quality across eight standards at institutional level and six standards at academic program level (NCAAA, Standards for Institutional Accreditation, 2018, Standards for Program Accreditation, 2018). Developing internal quality system in higher education in the Kingdom of Saudi Arabia is considered as one of the main challenges to HEIs [21]. Quality in universities and higher education institutes like any other systems has three main dimensions; inputs, the process and the outputs, also includes the interactions with the actors and the other systems to achieve the core functions and producing the major outcomes or outputs of teaching/ learning (graduates), research, and community service as shown in Fig. 1 [21].

TABLE. I. MOST IMPORTANT REQUIREMENTS FOR THE HIGHER EDUCATION ERP SYSTEM. SOURCE: [14] [23]

\begin{tabular}{|l|l|l|l|}
\hline \multicolumn{2}{|l|}{ Functional Requirements } & \multicolumn{2}{l|}{ Non- Functional Requirements } \\
\hline 1 & \multicolumn{1}{|l}{ Institution profile } & 1 & Accessibility \\
\hline 2 & Staff profile & 2 & Documentation \\
\hline 3 & Student profile & 3 & Efficiency \\
\hline 4 & Curriculum & 4 & Effectiveness \\
\hline 5 & Performance analysis & 5 & Extensibility \\
\hline 6 & Attendance (Staff / Students) & 6 & Fault tolerance \\
\hline 7 & Online examination & 7 & Interoperability \\
\hline 8 & Online assignment & 8 & Privacy \\
\hline 9 & Admission & 9 & Quality of Output \\
\hline 10 & Academic advising & 10 & Response time \\
\hline 11 & Timetable & 11 & Scalability \\
\hline 12 & Internal messaging & 12 & Security \\
\hline 13 & Alumni management & 13 & Stability \\
\hline 14 & Library management & 14 & Supportability \\
\hline 15 & Payroll & 15 & Testability \\
\hline 16 & Accounting & & \\
\hline 17 & Fees management & & \\
\hline 18 & Asset Management & & \\
\hline 19 & Ad hock reporting & & \\
\hline 20 & Job / requirements analysis & & \\
\hline 21 & Labor market demand & & \\
\hline 22 & $\begin{array}{l}\text { Education / labor market } \\
\text { observatory }\end{array}$ & & \\
\hline
\end{tabular}

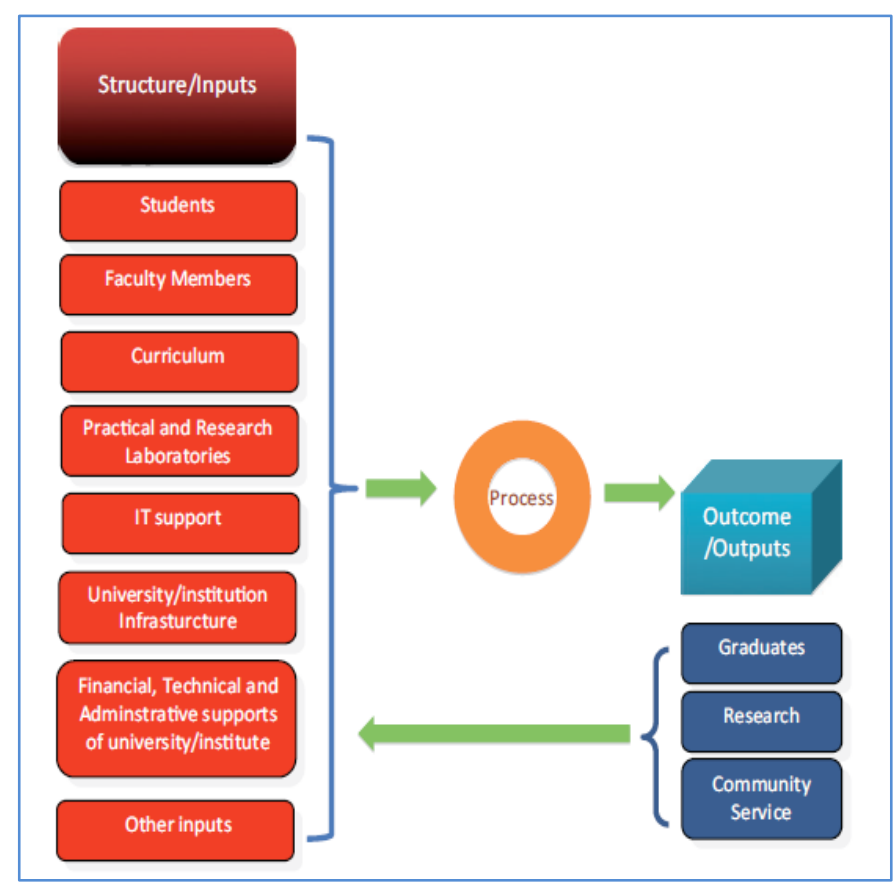

Fig. 1. Dimensions of Quality in Higher Education. Source: [21].

To develop the quality system and implement its core processes as shown in Fig. 1, the university administration must adhere to quality policies including set of processes (quality planning, quality assurance and quality control) and the active participation of all faculty, administrative staff and students. This requires the provision of financial and technical support [21], by the provision of an information system that assists all actors of the quality system in collecting, processing, storing and retrieving data to obtain performance indicator data and to produce periodic reports to meet quality and academic accreditation requirements, Academic accreditation requires data collection on various aspects of the institution and decision-making in compliance with standards [19]. The accessibility to data, information and records related to the quality processes and requirements for all staff through the most effective channels are very important [22]. The main problems of implementing quality system in HEIs are related to collect accurate information from several sources, working with huge information and documents, then analyzing this information to generate reports and KPIs results [9]. The implementation of information systems such as (ERP) will support the integration of quality assurance processes in HEIs and produce assessable information to meet quality requirements. ERP systems vendors for HEIs such as Oracle, SAP, People Soft and Jenzabar do not develop an ERP solution to cover all HEIs demands [9], mainly quality assurance requirements or even academic accreditation. The literature review supports the objectives of this research, as these literature reflect the widespread use of ERP systems in higher education institutions, including universities in Saudi Arabia, but these systems need to be developed to support processes related to quality and academic accreditation in terms of linking these processes with other components in Enterprise. As well as the collection, storage and retrieval of data related to academic accreditation processes, this calls for the concept of 
developing a special unit of quality and academic accreditation in the ERP system to help meet the new needs of higher education institutions.

\section{RESEARCH MethodOlOGY}

The research methodology based on content analysis method which includes (1) analyzing the content of research papers related to ERP system, Quality and Academic accreditation in HEIs. (2) semi-structured interviews with five ERP systems vendors in KSA and (3) NCAAA quality requirements and academic accreditation standards and documents. (4) Analysis of user requirements for those who are responsible for quality assurance in Dar Al Uloom University. This methodology aims to achieve the following research objectives:

- Determine the common ERP modules in higher education institutions.

- Propose a new module for quality and academic accreditation to collect accurate information from several sources, working with huge information and documents, then analyzing this information to generate reports and KPIs results related to quality and accreditation process.

- Link the proposed module with the ERP modules and other systems at the University to form a proposed conceptual framework for all ERP components in higher education institutions.

The conceptual framework proposed in this study consists of two main interrelated components, The first component contains the main modules of the ERP system that are suited to the work environment and organizational context in HEIs such as strategic planning, governance systems, human resources, elearning systems and student information systems, enterprise resources (finance, supply chain, warehouses, etc.), and Customers Relationship Management CRM. The identification of these modules will be relied upon studying the common functional requirements of ERP systems which used in HEIs in Saudi Arabia. This component will cover the first objective of the study, which is Determine the common ERP modules in higher education institutions. The second component will cover the second and third objective of the study, which is a proposed module dealing with the requirements of quality and academic accreditation (QAAM: Quality Assurance and Accreditation Module) aims to collect data, documents and forms preparation, data aggregation, data analysis, collecting evidences and reports generation based on Accreditation bodies standards, specially NCAAA. This module is linked with ERP modules in the first Component of the proposed framework through the data warehouse of the institution to provide data, statistics and reports related to quality processes and academic accreditation. QAAM also has interfaces that enable users to feed the system with the required data or to obtain data, statistics and reports that help them meet the requirements of quality and academic accreditation. Fig. 2 shows the high-level context of the proposed framework which explains the logical connectivity between the proposed framework components and the institution legacy systems, Learning Management System (LMS), Student Information System (SIS) and Data Warehouse.

\section{A. Component One: main Modules of the ERP System}

By reviewing the literature and the interviews with a group of service providers in Saudi Arabia such (Oracle, SAP, Infor, etc.) and (ODES, MADAR and Moraslat), the functionality of main modules of ERP are common and almost similar in ERP providers solutions. To give more focus on these functionalities which related to HEI, ERP modules should cover the functional and non-functional requirements which are mentioned in Table I. The proposed framework will consider all these functionalities.

\section{B. Component Two: QAAM: Quality Assurance and Accreditation Module}

Component two (QAAM) is the main module of the proposed framework, which aims to facilitate many processes related to quality and accreditation requirements. Fig. 3 shows the main components of QAAM, which is cover all NCAAA standards and requirements.

1) NCAAA standards interfaces: QAAM provides an interface for each standard of NCAAA standards, these interfaces will help the users to feed the systems with the required data and evidence. Also, the user can access the databases and reports related to QAAM.

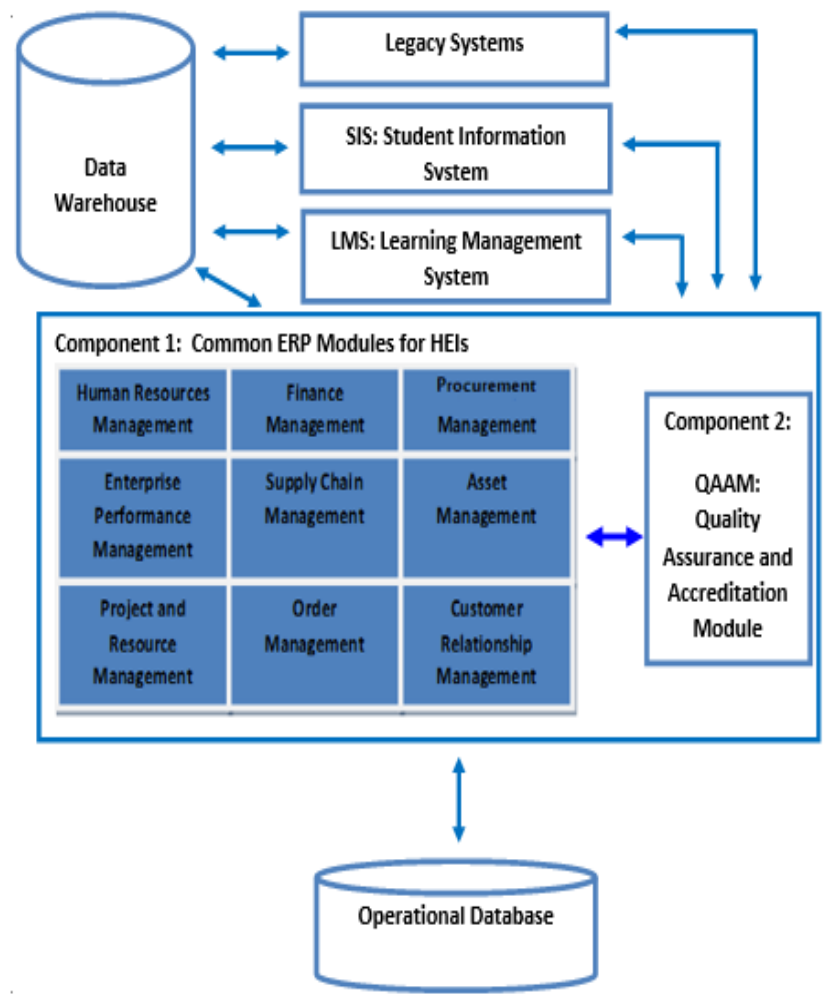

Fig. 2. Shows the High-Level Context of the Proposed Framework. 


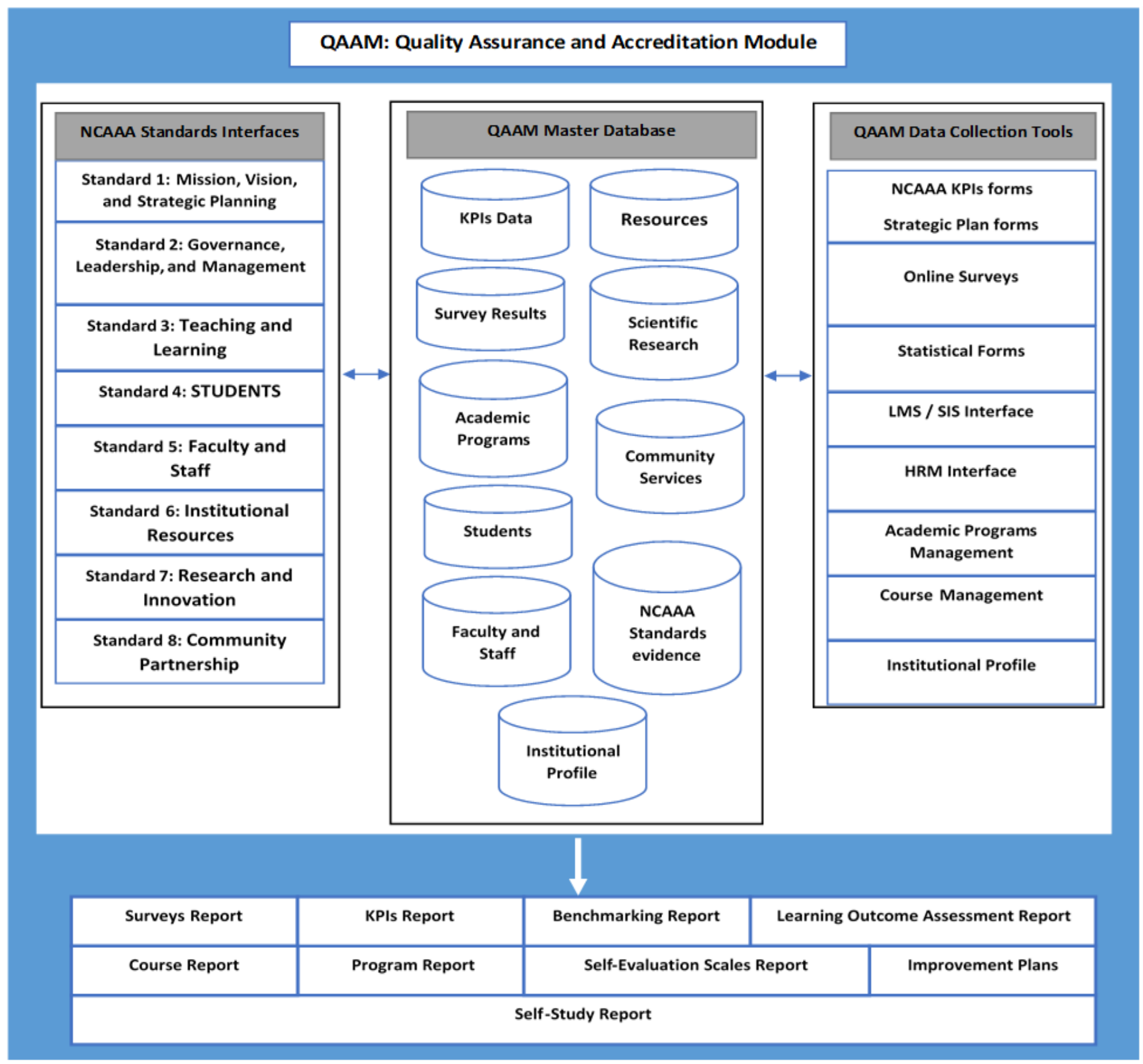

Fig. 3. Shows the Components of the Proposed Quality Module QAAM.

2) QAAM Master Database: The main purpose of QAAM master database is to collect all data of quality assurance and accreditation in one single database, this database is integrated with the other sub-systems of the proposed framework to exchange data and connected with NCAAA standards interfaces to allow users to read and write on specific data fields. Also, QAAM Data Collection Tools will feed this database with the required data and evidence. Table II shows a description for each component of QAAM master database.

3) QAAM Data Collection Tools: QAAM Master Database is depended on set of tools to collect the requited data related to the functionalities of this proposed modules. Table II mapped the components of QAAM Master Database with these tools. Table III shows a description for each tool of data collection tools.

4) Main QAAM Reports: QAAM Master Database and Data collection tools are explained in Tables II and III which aim to provide set of reports on quality requirements and academic accreditation to achieve the primary goal of the proposed framework that system users expect to obtain as basic products on which decisions and improvement plans are based and which will be presented to the accreditation bodies. Table IV shows a description for each of the reports could by generated by the system. 
TABLE. II. COMPONENTS OF QAAM MASTER DATABASE

\begin{tabular}{|c|c|c|c|c|}
\hline No. & Database Component & The Stored Data & Data Source & $\begin{array}{l}\text { Related } \\
\text { Standards }\end{array}$ \\
\hline 1 & KPIs Data & Used to store all NCAAA KPIs and Strategic Plan KPIs. & $\begin{array}{l}\text { - KPIs Forms. } \\
\text { - Strategic Plan Forms. }\end{array}$ & All \\
\hline 2 & Survey Results & Used to store all surveys feedbacks and results. & Online surveys. & All \\
\hline 3 & Academic Programs & $\begin{array}{l}\text { Used to store all data related to each academic program } \\
\text { (Program Specifications, Learning Outcomes } \\
\text { Assessments, Courses, etc.) }\end{array}$ & $\begin{array}{l}\text { - Statistical Forms. } \\
\text { - LMS/ SIS Interfaces. } \\
\text { - Academic Program Management. } \\
\text { - Course Management. }\end{array}$ & Standard 3 \\
\hline 4 & Students & Used to store all data related to the students. & $\begin{array}{l}\text { - Statistical Forms. } \\
\text { - LMS/ SIS Interfaces. } \\
\text { - Academic Program Management. } \\
\text { - Course Management. }\end{array}$ & Standard 4 \\
\hline 5 & Faculty and Staff & Used to store all data related to Faculty and Staff. & HRM Interface & Standard 5 \\
\hline 6 & Resources & $\begin{array}{l}\text { Used to store all data related to } \\
\text { Institutional Resources includes related to Financial } \\
\text { Resources and Budget, Information Technology, Facilities } \\
\text { and Equipment }\end{array}$ & $\begin{array}{l}\text { - Connected with ERP Modules (Finance } \\
\text { Management, Project and Resource } \\
\text { Management, Asset Management) }\end{array}$ & Standard 6 \\
\hline 7 & Scientific Research & $\begin{array}{l}\text { Used to store all data related to Scientific Research at } \\
\text { institutional and program levels. }\end{array}$ & - Statistical Forms. & Standard 7 \\
\hline 8 & Community Services & $\begin{array}{l}\text { Used to store all data related to Community Services at } \\
\text { institutional and program levels. }\end{array}$ & - Statistical Forms. & Standard 8 \\
\hline 9 & $\begin{array}{l}\text { NCAAA Standards } \\
\text { Evidence }\end{array}$ & $\begin{array}{l}\text { Store all evidence of NCAAA standards and practices } \\
\text { (Documents Based) }\end{array}$ & - All NCAAA Standards Interfaces & All \\
\hline 10 & Institutional Profile & $\begin{array}{l}\text { Used to store all data related to institutional profile which } \\
\text { includes general information and statistics about the } \\
\text { institution. }\end{array}$ & $\begin{array}{l}\text { - Statistical Forms. } \\
\text { - LMS/ SIS Interfaces. } \\
\text { - institutional profile tool. }\end{array}$ & All \\
\hline
\end{tabular}

\section{DISCUSSION}

The proposed a framework (Fig. 2) aims to facilitate the collection of required data from various sources within the university and helps to provide the necessary reports and statistics related to quality and accreditation. A set of quality and accreditation standards linked to human, financial resources and institution asset which could be covered by Component 1: Common ERP Modules for HEIs. ERP modules are used in universities and provided by the most known ERP system providers such as SAP, Oracle, PeopleSoft, also provided by ODES, MADAR and Moraslat. While Component 2, QAAM: Quality Assurance and Accreditation Module is the proposed module which plays a fundamental role in collecting data and generating reports directly related to all accreditation standards through four parts. The first part is NCAAA Standards Interfaces, which is the link between accreditation standards and users. This part relates to the database of the Quality and Accreditation Module. QAAM Master Database (second part of QAAM) store all evidence, data, performance indicators and statistics for each of the accreditation standards, which makes it easier for the user to access them easily and effectively without wasting time searching for them separately and also allows the user to amend and improve on that data and write the necessary comments for each standard in a participatory way between users which reflect those comments on the reports issued by the system, and it also unifies the mechanisms of work among the users without any conflict or inconsistency in the data, which helps in issuing the reports necessary for academic accreditation, Table II explains the role for each component of QAAM Master Database. The third part of the proposed module (QAAM Data Collection Tools) is extremely important as it represents the tools used to collect data and statistics necessary for each academic accreditation standard and store them in the database. The importance of this part comes from the fact that data, statistics, evidence and performance indicators are collected from a variety of sources that are difficult for the user to collect in a traditional way, for example, students' opinion on the quality of teaching courses, with many courses available, there is a need for tools to collect and analyze, so it is used Online survey tool to do this complex process. Each accreditation standard also has a set of performance indicators and statistics that are periodically compiled. Therefore, the data collection tools proposed in this model work to collect a large amount of data, organize and store it in an accurate way to be used by all users of the system, and this is one of the most important services that the user is satisfied with. Table III explains the purpose of each data collection tool. To create a business intelligence environment in the proposed framework, Data Warehouse is used to support QAAM Data Collection Tools by extracting raw data from various business systems and data sources in order to reveal meaningful knowledge, Data Warehouse a large relational database that combines pertinent data in an aggregate, summarized form suitable for enterprise wide data analysis, reporting, and management decision making, Data Mart is subset of a data warehouse that is usually designed for a specific set of users to provide them a specific data. The final product of the proposed framework and the proposed quality module QAAM is the extraction of the final reports of the quality and academic accreditation (Part Four) which depend 
on the integration of all other parts of the proposed framework, as the process of preparing these reports is extremely difficult due to the lack of evidence, data, indicators and statistics associated with each standard. This framework facilitates the process of issuing these reports in an automated way as they relate to the databases of QAAM as well as through comments provided by the user through NCAAA Standards Interfaces.

TABLE. III. QAAM DATA COLLECTION TOOLS

\begin{tabular}{|c|c|c|c|}
\hline No. & $\begin{array}{l}\text { Data Collection } \\
\text { Tools }\end{array}$ & Description & Integrated with \\
\hline 1 & $\begin{array}{l}\text { NCAAA KPIs } \\
\text { Forms. }\end{array}$ & $\begin{array}{l}\text { Used to collect: } \\
\text { - NCAAA KPIs ( } 23 \text { KPIs at Institutional Level and } 17 \text { at Program Level). } \\
\text { - Strategic Plan KPIs. } \\
\text { - Other Performance Indicators. } \\
\text { - Input data by the users. }\end{array}$ & $\begin{array}{l}\text { - ERP Modules. } \\
\text { - LMS/ SIS Interfaces. }\end{array}$ \\
\hline 2 & Online Surveys. & $\begin{array}{l}\text { Used to collect client satisfaction in different domains: } \\
\text { - NCAAA Surveys (Course Evaluation Survey, Program Evaluation Survey, } \\
\text { Student Experience Survey, Employer Evaluation Survey and Alumni } \\
\text { Evaluation Survey). } \\
\text { - Institutional Surveys (Climate Survey, Faculty Members Satisfaction Survey, } \\
\text { Staff Satisfaction Survey, Vision \& Mission Surveys, All Services Clients } \\
\text { Satisfaction Surveys) }\end{array}$ & $\begin{array}{l}\text { - LMS/ SIS Interfaces. } \\
\text { - HRM Interface. } \\
\text { - Academic Programs Management. } \\
\text { - Course Management. }\end{array}$ \\
\hline 3 & Statistical Forms. & $\begin{array}{l}\text { Used to collect the statistical Data to feed all NCAAA standards and KPIs such as: } \\
\text { - All statistical Data related to the Students (registered, withdraw, delayed, } \\
\text { denied, transferred, failed, successful, excellent, participating in various } \\
\text { activities, etc.). } \\
\text { - All statistical Data related to Alumni. } \\
\text { - All statistical Data related to Employers } \\
\text { - All statistical Data related to HR. } \\
\text { - All statistical Data related to Libraries and Learning Resources. } \\
\text { - All statistical Data related to Scientific Research. } \\
\text { - All statistical Data related to Professional Development Processes. } \\
\text { - All statistical Data related to Community Services. } \\
\text { - All statistical Data related to Institutional Resources includes related to } \\
\text { Financial Resources and Budget, Information Technology, Facilities and } \\
\text { Equipment. }\end{array}$ & $\begin{array}{l}\text { - ERP Modules. } \\
\text { - LMS/ SIS Interfaces. } \\
\text { - HRM Interface. } \\
\text { - institutional profile. }\end{array}$ \\
\hline 4 & $\begin{array}{l}\text { LMS/ SIS } \\
\text { Interfaces. }\end{array}$ & $\begin{array}{l}\text { Used as an interface to link the proposed QAAM components with the LMS and } \\
\text { SIS systems to obtain student-related information, academic program } \\
\text { management, and courses management. }\end{array}$ & $\begin{array}{l}\text { - QAAM Components. } \\
\text { - SIS: Students Information System. } \\
\text { - LMS: Learning Management System. }\end{array}$ \\
\hline 5 & HRM Interface. & $\begin{array}{l}\text { Used as an interface to link the proposed QAAM components HRM Module in } \\
\text { ERP system. }\end{array}$ & $\begin{array}{l}\text { - QAAM Components. } \\
\text { - NCAAA KPIs Forms. } \\
\text { - Statistical Forms. }\end{array}$ \\
\hline 6 & $\begin{array}{l}\text { Academic } \\
\text { Programs } \\
\text { Management. }\end{array}$ & $\begin{array}{l}\text { This tool plays important role in managing academic programs such as: } \\
\text { - Program Design and Development Processes. } \\
\text { - Curriculum. } \\
\text { - Course Mapping. } \\
\text { - Program Specification. } \\
\text { - Program Reports. } \\
\text { - Graduate Attributes and Learning Outcomes. } \\
\text { - Learning Resources. } \\
\text { - Program Evaluation Survey. } \\
\text { - Student Experience Survey. } \\
\text { - Program KPIs. } \\
\text { - Quality of Teaching and Students' Assessment. } \\
\text { - Statistical Data of Program. }\end{array}$ & $\begin{array}{l}\text { - QAAM Components. } \\
\text { - LMS/ SIS Interfaces. } \\
\text { - ERP Modules. } \\
\text { - Online Surveys. } \\
\text { - NCAAA KPIs Forms. } \\
\text { - Statistical Forms. }\end{array}$ \\
\hline 7 & $\begin{array}{l}\text { Course } \\
\text { Management }\end{array}$ & $\begin{array}{l}\text { Used to manage all courses for each program: } \\
\text { - Course Specifications. } \\
\text { - Course Report. } \\
\text { - Course Materials. } \\
\text { - Course Evaluation Survey. } \\
\text { - Students Attendance Reports. } \\
\text { - Assessment Instructor Material. } \\
\text { - Course Learning Outcomes Assessment. } \\
\text { - Final grade reports. }\end{array}$ & $\begin{array}{l}\text { - QAAM Components. } \\
\text { - LMS/ SIS Interfaces. } \\
\text { - ERP Modules. } \\
\text { - Online Surveys. } \\
\text { - NCAAA KPIs Forms. } \\
\text { - Statistical Forms. }\end{array}$ \\
\hline
\end{tabular}




\begin{tabular}{|c|c|c|c|}
\hline 8 & $\begin{array}{l}\text { Institutional } \\
\text { Profile }\end{array}$ & $\begin{array}{l}\text { This tool is used to manage the Institutional Profile which is contains: } \\
\text { - Summary of the Institution History. } \\
\text { - Institution's Academic Units. } \\
\text { - List of the Institution's Achievements, Awards, and Significant } \\
\text { Accomplishments. } \\
\text { - Institutional Performance Indicators. } \\
\text { - Program Data. } \\
\text { - Students Statistics. } \\
\text { - Teaching Staff Statistics. } \\
\text { - Graduates Statistics. }\end{array}$ & $\begin{array}{l}\text { - QAAM Components. } \\
\text { - LMS/ SIS Interfaces. } \\
\text { - ERP Modules. } \\
\text { - NCAAA KPIs Forms. } \\
\text { - Statistical Forms. }\end{array}$ \\
\hline
\end{tabular}

TABLE. IV. MAIN QAAM REPORTS

\begin{tabular}{|c|c|c|}
\hline No. & Main QAAM Reports & Description \\
\hline 1 & Surveys Report & Includes analysis of each NCAAA Surveys and Institutional Surveys distributed by Online Survey Tool. \\
\hline 2 & KPIs Report & $\begin{array}{l}\text { Three types of KPIs analysis reports. First report is related to NCAAA KPIs at institutional level ( } 23 \mathrm{KPIs}) \text {. Second } \\
\text { report is related to NCAAA KPIs at program level (17 KPIs). Third report is related to strategic Plan. }\end{array}$ \\
\hline 3 & Benchmarking Report & $\begin{array}{l}\text { Four types of Benchmarking Reports. Two reports at institutional level (Internal and External Benchmarking } \\
\text { Reports). Two reports at program level (Internal and External Benchmarking Reports). }\end{array}$ \\
\hline 4 & $\begin{array}{l}\text { Learning Outcome Assessment } \\
\text { Report }\end{array}$ & $\begin{array}{l}\text { Comprehensive Learning Outcome Assessment Report includes Course / Program / Institution Learning Outcomes } \\
\text { Assessment Report. This report. This report compares the current and previous targets for learning outcomes and } \\
\text { analyzes the results to develop improvement plans and define new targets for learning outcomes. }\end{array}$ \\
\hline 5 & Course Report & $\begin{array}{l}\text { The course report is one of the most important requirements of NCAAA Requirements to monitor the quality of } \\
\text { teaching courses and ensure continuous improvement. This report includes information about students in the course } \\
\text { and their results, checking the appropriateness of teaching strategies and assessment methods for the course, results } \\
\text { of measuring learning outcomes for the course, assessing the quality of the course by beneficiaries and management. } \\
\text { Development of course improvement plans }\end{array}$ \\
\hline 6 & Program Report & $\begin{array}{l}\text { Based on NCAAA requirement, each academic program must issue an annual report on the quality of the program at } \\
\text { the end of the academic year (Annual Program Report). This Report includes Program Statistics, Results of Program } \\
\text { Learning Outcomes Assessment, Result Analysis of Course Reports, Program Activities, Program Evaluation and } \\
\text { Program Improvement Plan. }\end{array}$ \\
\hline 7 & Self-Evaluation Scales Report & $\begin{array}{l}\text { Two types of Self-Evaluation Scales Report, one at institutional level and the other at program level. This report } \\
\text { aims to help those responsible for quality assurance at institutional / Program Levels to conduct evaluation in an } \\
\text { objective manner based on the institutional/programmatic quality assurance standards prepared by NCAAA. This } \\
\text { document can also be used in the field of planning, internal auditing, and supporting strategies to improve } \\
\text { institutional quality and the quality of academic programs in Institutions of higher education. }\end{array}$ \\
\hline 8 & Improvement Plans & $\begin{array}{l}\text { All previous reports help quality officials and decision makers develop improvement plans. This report is concerned } \\
\text { with following up on what has been achieved of improvement initiatives at various levels of the institution. }\end{array}$ \\
\hline 9 & Self-Study Report & $\begin{array}{l}\text { The self-study report is the most important products of the proposed framework, which depends on all previous } \\
\text { reports and on all proposed databases. The self-study report is an extensive examination of the quality of the } \\
\text { educational institution or academic program in accordance with the quality assurance and accreditation standards set } \\
\text { by NCAAA, linking them to the evidence, statistics and analyzes associated with them. Data warehouse of the } \\
\text { proposed framework will provide set of data mart to feed the Self-Study Report. }\end{array}$ \\
\hline
\end{tabular}

This study provided a conceptual framework that is proposed to add a special module for quality and academic accreditation QAAM that is associated with the ERP system in the educational institution and other systems to facilitate the process of collecting, organizing and storing data, evidence and performance indicators for academic accreditation and issuing final reports. This framework aims to achieve the study objectives and to cover the functional and non-functional requirements in Table I as well as dimensions of quality in higher educational institutions in Fig. 1, for the purpose of covering the quality requirements and academic accreditation of National Center for Academic Accreditation and Assessment (NCAAA).

\section{CONCLUSION AND FUTURE WORK}

Higher education institutions have relied on information systems for carrying out their operations and managing their data for several decades. However, the structure of these systems is evolving as the needs of these institutions evolve.
HEIs have started adopting ERP systems to ensures the integration of all the operations and data of the organization. One of the modern needs of higher education institutions is compliance with local and international quality and accreditation standards. As this has become one of the real challenges in collecting, linking and analyzing data to extract the necessary reports for this institution to be eligible to progress and obtain academic accreditation through the application of an effective quality system that ensures continuous improvement in academic processes and services provided to beneficiaries. Due to the diversity of data sources and challenges faced by those responsible for academic quality requirements in preparing evidence, files, statistics and performance indicators in accordance with academic accreditation standards, the main purpose of this study is to provide a conceptual framework that links the institution's systems with each other. The framework provides Quality Assurance and Accreditation Module (QAAM) as part of the ERP system and it undertakes a task Facilitate the work of 
collecting and analyzing all data related to quality and academic accreditation and issuing their reports such as performance indicator reports, program reports, academic courses and self-evaluation report, which helps in development of improvement plans and finally generating the self-study report, through an interactive interfaces between the system and the users that enable them to obtain data, evidence and reports and allow the users to feed the system with appropriate information and comments.

Future work leads us to implement this proposed framework, and to study its ability to achieve the goals for which it was created. It is also proposed to apply it widely among higher education institutions and to benefit from automated benchmarking between these institutions based on the performance indicators reports issued by the system, as the external benchmarking is also a requirement of quality and academic accreditation.

\section{REFERENCES}

[1] Abugabah A., Sanzogni L. and Alfarraj O., (2015), "Evaluating the impact of ERP systems in higher education". The International Journal of Information and Learning Technology Vol. 32 No. 1, 2015 pp. 45-64 OEmerald Group Publishing Limited 2056-4880. DOI 10.1108/IJILT10-2013-0058.

[2] Pollock and Cornford (2004), "ERP systems and the university as a "unique" organisation". Information Technology \& People Vol. 17 No. 1, 2004 pp. 31-52. Emerald Group Publishing Limited 0959-3845 DOI $10.1108 / 09593840410522161$.

[3] SABAU G., MUNTEN M., BOLOGA A., BOLOGA R. and SURCEL T (2009), "An Evaluation Framework for Higher Education ERP Systems". WSEAS TRANSACTIONS on COMPUTERS. Issue 11, Volume 8, November 2009. ISSN: 1109-2750.

[4] Rico, D. F. (2004). "ERP in higher education". Retrieved 6 September, 2019, from: http://davidfrico.com/rico04f.pdf.

[5] Abugabah A. and Sanzogni L. (2010), "Enterprise Resource Planning (ERP) System in Higher Education: A literature Review and Implications". World Academy of Science, Engineering and Technology International Journal of Computer and Systems Engineering Vol:4, No:11, 2010.

[6] Hamdatu M., Siddiek A. and Al-Olyan F. (2013), "Application of Quality Assurance \& Accreditation in the Institutes of Higher Education in the Arab World (Descriptive \& Analytical Survey)". American International Journal of Contemporary Research Vol. 3 No. 4; April 2013.

[7] Abou-Zeid A. and Taha M., (2014), "Accreditation Process for Engineering Programs in Saudi Arabia: Challenges and Lessons Learned". IEEE Global Engineering Education Conference (EDUCON). 3-5 April 2014, Military Museum and Cultural Center, Harbiye, Istanbul, Turkey.

[8] Yvonne Lederer, A., Gail, C., Glenn, S. and Albert, L.H. (2004), "Enterprise systems education: where are we? Where are we going?", Journal of Information Systems Education, Vol. 15 No. 3, pp. 227-233.
[9] Kahveci T., Uygun, Yurtsever, Ulaş and Sinan (2012), "Quality Assurance in Higher Education Institutions Using Strategic Information Systems". In 3rd. International Conference on New Horizons in Education - INTE 2012, Procedia - Social and Behavioral Sciences. 5 October 2012 55:161-167 DOI: 10.1016/j.sbspro.2012.09.490, Database: ScienceDirect.

[10] Sowan I., Tahboub R. and Khamayseh (2017), "University ERP Preparation Analysis: A PPU Case Study". (IJACSA) International Journal of Advanced Computer Science and Applications, Vol. 8, No. $11,2017$.

[11] Rani (2019), "A Review of ERP Implementation in Higher Education Institutions". International Journal of Advanced Research in Computer Science and Software Engineering. Volume 6, Issue 6, June 2016 ISSN: 2277 128X.

[12] Davis, M. and Huang, Z., (2007), "ERP in higher education: a case study of SAP and campus management", Issues in Information Systems, Vol. 8 No. 1, pp. 120-126.

[13] Kvavik, R., Katz, R., Beecher, K., Caruso, J. and King, P. (2002), "The promise and performance of enterprise systems for higher education", Educause, Vol. 4 No. 1, pp. 5-123.

[14] Noaman and Ahmed (2015), "ERP Systems Functionalities in Higher Education," Procedia Computer Science, vol. 65, pp. 385-395, 2015.

[15] Materu, P. (2007), "Higher Education Quality Assurance in Sub-Sahara Africa - Status, Challenges, Opportunities and Promising Practices". Washington, D.C: World Bank working paper No. 124, Africa Region Human Development Department, The World Bank.

[16] INQAAHE. (2011). "Operating an External Quality Agency".

[17] Islam, Ali and Islam (2017), "Quality Assurance and Accreditation Mechanisms of Higher Education Institutions: Policy Issues and Challenges in Bangladesh". European Journal of Education Studies ISSN: 2501 - 1111 ISSN-L: 2501 - 1111. doi: 10.5281/zenodo.495792.

[18] Abu Jaber and Al Batsh (2016), "Jordanian Experience in Accreditation and Quality Assurance in HEIs". US-China Foreign Language, April 2016, Vol. 14, No. 4, 312-327 doi:10.17265/1539-8080/2016.04.007.

[19] Al Mohaimeed A., Midhet F., Barrimah I. and Saleh M., (2012), "Academic Accreditation Process: Experience of a Medical College in Saudi Arabia". International Journal of Health Sciences, Qassim University, Vol. 6, No. 1 (Jan 2012/ Safar 1433H).

[20] Alalfy H., Al-Aodah I. and Shalaby E., (2013), "Role of Development and Accreditation Deanship for Qualification of Hail Faculties, Saudi Arabia for Local Accreditation". Greener Journal of Educational Research ISSN: 2276-7789 Vol. 3 (3), pp. 123-133, May 2013.

[21] Al-shafei A., Abdulrahman K., Al-Qumaizi K. and El-Mardi A. (2015), "Developing a generic model for total quality management in higher education in Saudi Arabia". Medical Teacher. 37:sup1, S1-S4, DOI:10.3109/0142159X.2015.1006607.

[22] Mahbub (2017), "Quality Assurance for Higher Education: Challenges in Sustaining Continuous Quality Improvement for Malaysian Universities". Proceedings ff Inted2017 Conference 6th - 8th March 2017, Valencia, Spain, ISBN: 978-84-617-8491-2.

[23] Soliman and Karia (2015), "Enterprise Resource Planning Systems in Higher Education Context: Functionalities and Characteristics". International Journal of Innovative Research in Science, Engineering and Technology. Vol. 4, Issue 11, November 2015. ISSN (Online): 2319-8753. ISSN (Print): 2347-6710. 